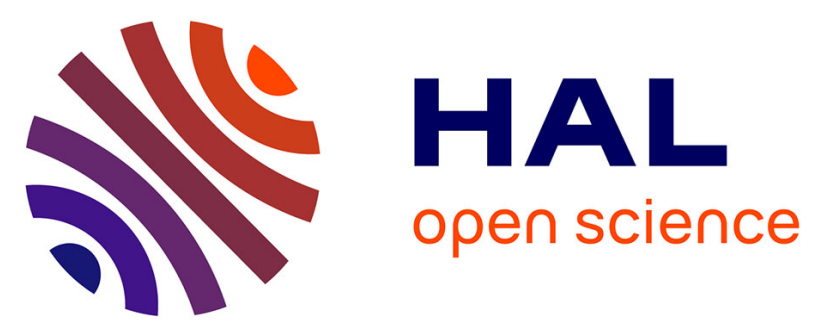

\title{
Assessment of the specificity of a new folate-targeted photosensitizer for peritoneal metastasis of epithelial ovarian cancer to enable intraperitoneal photodynamic therapy. A preclinical study.
}

Henri Azais, Caroline Schmitt, Meryem Tardivel, Olivier Kerdraon, Aurélie

Stallivieri, Céline Frochot, Nacim Betrouni, Pierre Collinet, Serge Mordon

\section{To cite this version:}

Henri Azais, Caroline Schmitt, Meryem Tardivel, Olivier Kerdraon, Aurélie Stallivieri, et al.. Assessment of the specificity of a new folate-targeted photosensitizer for peritoneal metastasis of epithelial ovarian cancer to enable intraperitoneal photodynamic therapy. A preclinical study. . 2015. hal01183340

\author{
HAL Id: hal-01183340 \\ https://hal.science/hal-01183340
}

Submitted on 7 Aug 2015

HAL is a multi-disciplinary open access archive for the deposit and dissemination of scientific research documents, whether they are published or not. The documents may come from teaching and research institutions in France or abroad, or from public or private research centers.
L'archive ouverte pluridisciplinaire HAL, est destinée au dépôt et à la diffusion de documents scientifiques de niveau recherche, publiés ou non, émanant des établissements d'enseignement et de recherche français ou étrangers, des laboratoires publics ou privés. 


\title{
Assessment of the specificity of a new folate-targeted photosensitizer for peritoneal metastasis of epithelial ovarian cancer to enable intraperitoneal photodynamic therapy. A preclinical study.
}

\author{
AZAïS Henri ${ }^{1,2}$, SCHMITT Caroline ${ }^{3}$, TARDIVEL Meryem ${ }^{4}$, KERDRAON Olivier ${ }^{5}$, \\ STALLIVIERI Aurélie ${ }^{6}$, FROCHOT Céline ${ }^{6}$, BETROUNI Nacim ${ }^{1}$, \\ COLLINET Pierre ${ }^{1,2}$, MORDON Serge ${ }^{1}$.
}

1- INSERM U1189 - ONCO-THAI, University of Lille, 59000 Lille, France.

2- Department of Gynecology, University of Lille, 59000 Lille, France.

3- Centre Français des Porphyries, Assistance Publique - Hôpitaux de Paris, Hôpital Louis Mourier, Colombes, France and INSERM U1149, Paris Diderot University, 75018 Paris, France.

4- Plate-forme d'imagerie cellulaire BICEL - IFR 114. Pôle recherche, University of Lille, 59000 Lille, France.

5- Centre de biologie-pathologie, University of Lille, 59000 Lille, France.

6- Laboratoire Réactions et Génie des Procédés, UMR 7274 CNRS - University of Lorraine, France.

\author{
Corresponding Author \\ Henri AZAÏS \\ INSERM U1189 - ONCO-THAI \\ University of Lille \\ 1, avenue Oscar Lambret \\ 59037 Lille - France \\ henriazais@gmail.com
}

Highlights 
- Folate-targeted photosensitizer is specific of peritoneal metastasis.

- Folate-targeted photosensitizer is a promising candidate for intraperitoneal PDT.

- Tumor-to-tissue ratio of 9.6 should permit to illuminate the peritoneal cavity.

\section{INTRODUCTION}

The prognosis of advanced epithelial ovarian cancer remains poor. The current treatment is the association of complete macroscopic cytoreductive surgery and platinum-based chemotherapy. It is accepted that the absence of residual disease after surgery is a key to improve prognosis ${ }^{[1,2]} .60 \%$ of patients treated by complete cytoreductive surgery and chemotherapy will develop peritoneal recurrence ${ }^{[3]}$.

Peritoneal cavity must be oncologically considered as an organ in its own right ${ }^{[4]}$ and the surgeon must treat peritoneal metastasis with a curative intent. Our aim is to provide another option to improve the completion of cytoreductive surgery by inducing necrosis of micrometastasis by targeted photodynamic therapy (PDT) and so to decrease the incidence of recurrence. PDT is a non-invasive ways of treating malignant tumors that is clinically applied in wide range of medical conditions. In the photodynamic reaction, after ligth absorption, the photosensitizer (PS) is promoted to an excited singlet state and then to a triplet state that transfers its energy to oxygen leading to the production of highly toxic reactive oxygen species such as singlet oxygen. The selectivity of the treatment is brought by light, the photosensizer being active only after irradiation. A limit of this technique is the toxicity induced by the low PS specificity for tumor tissue if the light cannot be specifically applied. This would be the case in peritoneal metastasis in advanced ovarian cancer. To solve this problem, a solution is the design of selective PS, that is to say PS coupled to an unit that target over-expressed receptors on tumoral cells. 
Folate receptor alpha $(F R \alpha)$ is a promising target as it is highly specific of epithelial ovarian cancer ${ }^{[5,6]}$. It is a well-known tumor associated protein that can actively internalize bound folates via endocytosis allowing delivering high concentrations of cytotoxic agent to tumor expressing high levels of the folate receptor ${ }^{[7]}$. In previous studies we already demonstrated the potential of folate-targeted porphyrin or chlorin in vitro and in vivo to improve the selectivity of the PS and the improvement of PDT efficiency ${ }^{[8,9]}$. Our objective is to assess the specificity of a new generation photosensitizer ( $\mathrm{N}-\{2-[2-(2$-aminoethoxy)ethoxy]ethyl\}folic acid\}-4-carboxyphenylporphyrin) targeted by folate (called Porph-s-FA) for ovarian peritoneal metastasis in a preclinical study.

\section{MATERIAL AND METHODS}

\section{Preclinical model of peritoneal carcinomatosis (ovarian cancer)}

Pathogen-free Fischer 344 female rats $(140-160 \mathrm{~g})$ were obtained from HARLAN Laboratories (Gannat, France). They were housed in a pathogen-free animal facility and given commercial basal diet and water ad libitum. The protocol was approved by our animal use and ethic committee (DHURE - Departement Hospitalo-Universitaire de Recherche Expérimentale), University of Lille, France $\left(n^{\circ}=59-350120\right)$.

NuTu-19 is a syngeneic adenocarcinoma used to develop ovarian cancer in an immunocompetent rat model ${ }^{[10]}$. It is a poorly differentiated adenocarcinoma originally derived from a female athymic mouse after injection of Fischer 344 ovarian surface epithelial cells that spontaneously underwent malignant transformation in vitro.

NuTu-19 cells were cultured in DMEM (Gibco Life Technologies, Grand Island, NY, USA) supplemented with $10 \%$ heat-inactivated fetal bovine serum, penicillin $1 \%$ and streptomycin $1 \%$. Cell culture plates were incubated under standardized conditions (5\% carbon dioxide, $100 \%$ humidity, $\left.37^{\circ} \mathrm{C}\right)$. The cell line was cryopreserved in liquid nitrogen $\left(10^{7} \mathrm{cells} / \mathrm{vial}\right)$. Each experiment was performed by thawing a vial of cells and expanding them biweekly to provide 
the appropriate cell number. After harvesting the NuTu-19 cells with $0.25 \%$ trypsin (Gibco Life Technologies ${ }^{\mathrm{TM}}$, NY, USA), they were washed with Dulbecco's phosphate-buffered saline (PBS, Gibco Life Technologies ${ }^{\mathrm{TM}}$, NY, USA) and counted. Viability was testing using trypan blue exclusion. With a minimum of $90 \%$ survival, $10^{6}$ cells $\mathrm{ml}^{-1}$ PBS were injected intraperitoneally in the Fischer rats. Small nodules up to $2 \mathrm{~mm}$ form along the peritoneal lining of the abdominal wall, pelvis, and omentum with haemorrhagic ascites.

This preclinical model enables to study folate-targeted therapy ${ }^{[11]}$.

\section{Photosensitizers}

5-(4-carboxyphenyl)-10,15,20-triphenylporphyrin $\quad$ (Porph) and $\quad \mathrm{N}\{2-[2-(2-$ aminoethoxy)ethoxy] ethylffolic acid\}-4-carboxyphenylporphyrin called Porph-s-FA (Figure 1) were provided by a French research laboratory (Laboratoire Réactions et Génie des Procédés, UMR 7274 CNRS - University of Lorraine, France) ${ }^{[9]}$ and were stored in powder form and kept refrigerated. Synthesis of this compounds have been described previously ${ }^{[9]}$. Samples were prepared immediately prior to use by dissolution of the powder in $200 \mu \mathrm{L}$ of DMSO first and then in phosphate buffered saline (PBS), and were protected from light exposure.

\section{Tissue sampling protocol}

18 rats were divided into three groups:

1) Control. No photosensitizer injected $(n=6)$.

2) Injection of 5-(4-carboxyphenyl)-10,15,20-triphenylporphyrin (Porph) $(n=6)$.

3) injection of $\mathrm{N}-\{2-[2-(2-a m i n o e t h o x y)$ ethoxy]ethyl\}folic acid\}-4-carboxyphenylporphyrin (Porph-s-FA) $(n=6)$

6-8 weeks, after peritoneal injection of NuTu-19 cells, the PS was administered. Each animal received an intraperitoneal injection of $3 \times 10^{-6} \mathrm{~mol} / \mathrm{kg}$ of Porph (group 2, $1.8 \mathrm{mg} / \mathrm{kg}$ ) or Porph-s-FA (group 3, $3.6 \mathrm{mg} / \mathrm{kg}$ ). Animals from group 1 didn't receive any injection. Animals 
were sheltered from light prior tissue sampling. 4 hours after administration, according to Gravier et al. ${ }^{[8]}$, they were anesthetized with isofluran and placed in the supine position to perform a precise surgical examination of the peritoneal cavity. Then, they were sacrificed by blood depletion, and sampling of the tissues (liver, kidney, colon, small intestine, ovary, peritoneum and tumor) was immediately performed under dim light. Peritoneal fluid was carefully wiped off the tissues and feces were evacuated from the intestine by gentle pressure.

Samples for PS tissue quantification were dropped into liquid nitrogen immediately after removal and then conserved at $-80^{\circ} \mathrm{C}$. Samples for histology analysis and confocal microscopy were dropped into formaldehyde solution for 24 hours and then into ethanol $70 \%$ before paraffin inclusion. All tissue samples were individually covered in aluminum to protect them from light exposure.

\section{FR $\alpha$ tissue expression by immunohistochemistry}

Tissue expression of FR $\alpha$ was determined for several organs of the peritoneal cavity. Two primary antibodies (Santa Cruz Biotechnology ${ }^{\mathrm{TM}}$ and Antibodies-online ${ }^{\mathrm{TM}}$ ) were previously tested and adjusted on human high grade serous ovarian carcinoma used as a positive control. Optimal staining was obtained with Santa Cruz Antibody ${ }^{\mathrm{TM}}$.

Tissue sections were fixed on glass slides. They were deparaffinised with xylene, rehydrated through a graded series of ethanol and rinsed in distilled water. Antigen retrieval was achieved by heating in EDTA buffer solution $\mathrm{pH} 8$ for $9 \mathrm{~min}$ at $98^{\circ} \mathrm{C}$. Slides were cooled down to room temperature and rinsed with PBS. After blocking endogenous peroxidase in $3 \% \mathrm{H}_{2} \mathrm{O}_{2}$ in PBS for $15 \mathrm{~min}$, sections were pre-treated by avidin/biotin reagents to reduce non-specific background. Sections were incubated with the primary antibody FL-257 (Santa Cruz Antibody $^{\mathrm{TM}}$ ) for $60 \mathrm{~min}$ in a 1:1000 dilution at room temperature. After washing with PBS, sections were incubated with secondary biotinylated anti-rabbit antibody. Peroxidase activity was visualized with 3,3-diaminobenzidine and slides were counterstained with haematoxylin, 
mounted with mounting medium and coverslips were added. All histology has been assessed by a senior pathologist.

\section{Accumulation Assay}

The uptake of the PS was examined in peritoneal carcinomatosis nodules, normal peritoneum, liver, colon, small intestine, kidneys and ovaries, after thawing of the samples.

$50 \mathrm{mg}$ tissue samples were carefully cut in $500 \mu \mathrm{L} 0,9 \%$ saline solution, then sonicated for three periods of 12 seconds (Bioblock Scientific ${ }^{\top M}$ ). Total protein concentration was determined using Coomassie Blue reagent (Protein Assay, BioRad Laboratories ${ }^{\mathrm{TM}}$ ). Porphyrins were extracted from the suspension by a ten-fold dilution with $1 \mathrm{~N}$ perchloric acid : methanol $(1: 1 \mathrm{v} / \mathrm{v})$. After mixing and centrifugation, the supernatant was isolated for quantification of PS by spectrofluorometry, using a VARIAN Cary Eclipse spectrofluorometer fitted with a red sensitive photomultiplier (excitation at $438 \mathrm{~nm}$, emission at $672 \mathrm{~nm}$ ). The results were given in nanomoles per gram of proteins. The different types of endogenous porphyrins in tissue were also determined by high pressure liquid chromatography (HPLC) and quantified (excitation at $410 \mathrm{~nm}$, emission at $600 \mathrm{~nm}$ ) (data not shown).

\section{In vivo visualization of photosensitizer uptake}

Tissue Porph-s-FA specific fluorescence was studied by confocal microscopy for each tissue sample of groups 1 (control) and 3 (Porph-s-FA). Tissue sections were fixed on glass slides. They were deparaffinised with xylene, rehydrated through a graded series of ethanol and rinsed in distilled water. Slides were then mounted with DAPI (Vectashield mounting medium for fluorescence with DAPI, Vector Laboratories ${ }^{\mathrm{TM}}$ ) and coverslips were added. For each organ, a control slide was mounted with mounted medium alone (Shandon ImmunoMount, Thermo Scientific ${ }^{\mathrm{TM}}$ ), to identify tissue autofluorescence emission. Slide preparation was performed under dim light.

Tissue slides were examined with an inversed confocal microscope Zeiss LSM 710 (Carl Zeiss $^{\mathrm{TM}}$, Jena, Germany), with 10x and 40x magnification. We used the ZEN 2010 software 
(Zeiss Efficient Navigation, Carl Zeiss ${ }^{T M}$, Jena, Germany) for pictures acquisition with an excitation wavelength at $405 \mathrm{~nm}$ and an emission wavelength at $650 \mathrm{~nm}$

\section{Statistical analysis}

The Wilcoxon test for matched samples was used for the statistical analysis using $\mathrm{JMP}^{\circledR}$ Pro 10.0.0 (SAS Institute Inc. - NC - USA) software. A p value $<0.05$ was considered significant.

\section{RESULTS}

\section{Expression of FRa in vitro and in vivo.}

The description of this preclinical model for folate-targeted therapy has been published elsewhere ${ }^{[11]}$. To assess the specificity of $\mathrm{FR} \alpha$ expression by tumor tissue, immunohistochemistry techniques were used to determine the specific expression of the receptor in several organs of the abdominal cavity. Ovary, peritoneum, small intestine, colon, liver, kidney and tumor tissue have been examined. Ovary, liver and tumor tissue showed FRa-positive cell contingents. On the contrary, peritoneum, small intestine, colon, kidney were FRa-negative tissue. In the ovary, the expression of FRa is mainly located at the epithelial surface of the organ. In the liver, FRa is expressed by cells located near the endothelium, which may correspond to human hepatic stellate cells.

\section{Cytoplasmic red endocytosis vesicles observed in confocal microscopy are well correlated to FR $\alpha$ tissue expression}

Figure 2 shows tissue expression of FRa observed on slide section of ovary, small intestine, colon, peritoneum, kidney, and liver. Confocal microscopy allows visualizing the fluorescence of Porph-s-FA 4 hours after administration (group 3). Folate-targeted PS appears in confocal microscopy under the form of a red vesicle of endocytosis which is absent in control tissue (group 1). Cell nuclei appear in blue after DAPI application. The specific red signal is cytoplasmic, and is different from red cell autofluorescence which is observed in extracellular 
space and with a larger size (approximately $7 \mu \mathrm{m}$ ). Some tissue (kidney, liver) are emitting autofluorescence, but this autofluorescence is similar between groups 1 and 3 and so independent of the PS administration.

Ovarian epithelium expresses FRa. Specific red signal indicating the presence of PS is observed in ovarian tissue after administration of Porph-s-FA. In the liver, we have observed the expression of FR $\alpha$ by cells locating near the endothelium and which could correspond to human hepatic stellate cells. A specific red signal in relation to accumulation of the folatetargeted PS was observed into the cytoplasm of those cells.

The study of colon, small intestine, kidney and peritoneum didn't demonstrate any expression of $F R \alpha$, and confocal microscopy images confirm these results since no fluorescence could be detected in those tissues.

In tumor tissue, a heterogeneous expression of $\mathrm{FR} \alpha$ was observed, and incorporation of Porph-s-FA was detected by confocal microscopy (Figure 3).

\section{Tissue quantification shows specificity of the folate-targeted photosensitizer}

Details of PS tissue quantification results are given on Tables 1-2 and Figures 4-5. Those results have been obtained only from bulk photosensitizer extraction of snap frozen specimens. PS quantification in the different organs allows providing precise information on the ratio of the incorporation in normal/tumoral tissues. A higher level of tissue concentration of PS was observed in tissues which express FRa (tumor, ovary and liver). On the contrary, low level of PS was observed in those tissues after administration of non-conjugated compound (Porph).

Due to the variable growth of peritoneal carcinomatosis in our model, we could provide only results from four samples originating from two rats of the third group. Those results range from 6.8 to $282 \mathrm{nmol} / \mathrm{g}$ prot (mean $87.30+/-131.17$ ) in the third group, as they range from 0.1 to $0.3 \mathrm{nmol} / \mathrm{g}$ prot (mean $0.19+/-0.09$ ) in the group 1 . We are unable to provide a 
statistical analysis regarding this poor number of data. Nevertheless, the order of magnitude isn't the same between group 3 and 1, and those results are in agreement with confocal microscopy observation, and with tissue receptor expression. By extrapolation, and based on literature data, as it has been shown that FRa expression was highly selective in epithelial ovarian cancer among women, a folate-targeted PS could be an answer to the lack of specificity of older non-targeted PS.

The mean tumor-to-normal tissue ratio in the "Porph-s-FA" group was 9.6. Ovary was the organ with the higher concentration of PS (tumor-to-ovary ratio: 2.5). This ratio calculated for liver, colon, peritoneum, small intestine and kidney was respectively $8.5 ; 26.7 ; 31 ; 48$ and 84.5 .

\section{DISCUSSION}

We report preclinical evidences to assess the high specificity of a folate-targeted photosensitizer which could enable intraperitoneal photodynamic therapy for peritoneal carcinomatosis of ovarian origin.

One unsolved issue in advanced ovarian cancer surgical management is the treatment of peritoneal metastasis which are ignored during surgery because of their small size, even with a fluorescence-guided surgical strategy to enhance the completion of the surgery, and particularly in the case of platinum resistance. Our aim is to develop a PDT (photodynamic therapy) procedure performed at the end of complete cytoreductive surgery to induce necrosis of undetectable lesion and improve cytoreductive strategy. Molecularly targeted PS have a strong clinical potential and are needed to improve therapeutic index of intraperitoneal PDT ${ }^{[12]}$. It is necessary to get a PS specific and a light of appropriate wavelength to decrease side effects of the procedure and improve its tolerance and efficacy. We have shown that this folate-targeted PS accumulate in the tissues which express FR $\alpha$ and that this incorporation is allowed by the conjugation with the folate, as non-conjugated 
PS is less incorporated into tissue. It is necessary to avoid intraperitoneal organs injuries. The observation of FRa expression and photosensitizer uptake by ovary hasn't any clinical relevance in this context as this organ isn't concern by this strategy, and always removed during cytoreductive surgery.

It has been stated by Elnakat and Ratnam that there is variability in the expression levels of the receptor among tumors obtained from different patients as well as heterogeneity in its expression within the same tumor ${ }^{[13]}$. We have observed a heterogeneous expression of folate receptor in the tumor tissue and this observation may have an impact regarding the efficacy of the photodynamic therapy procedure and interfere with the complete destruction of the tumor tissue. Regarding our findings, a limitation was that only a few commercial polyclonal antibodies were available to evaluate $\mathrm{FR} \alpha$ expression in a murine model, compared to the amount of antibodies available for human tissue applications. This could explain the low quality staining in tumor tissue. Nevertheless, two different commercial polyclonal antibodies (Santa Cruz Biotechnology ${ }^{T M}$ and Antibodies-online ${ }^{T M}$ ) were tested by an expert pathologist of Lille University Hospital, and adjusted with human high grade serous ovarian carcinoma. We observed specific staining in the tumor, and folate receptor, as a target, has several advantages ${ }^{[14]}$ : its expression profile seems to be similar between primary tumors and recurrences ${ }^{[5]}$, and chemotherapy hasn't any impact on receptor expression by residual lesions ${ }^{[15,16]}$.

Our folate-targeted PS has been first designed by Schneider et al., and its photodynamic efficacy has been assessed in vitro on KB cells which express folate receptor ${ }^{[9]}$. It has been shown that when conjugated to folate, porphyrin or chlorin (which are commonly used as PS) had a better selectivity for tumor tissue, a better solubility, less normal tissue cytotoxicity and a better photodynamic activity ${ }^{[8,17,18]}$. 
While recent folate-targeted chemotherapy, like vintafolide ${ }^{[19,20]}$, hasn't shown clinical evidences to improve prognosis of epithelial ovarian cancer, folate receptor remains a promising target among available tumor targets and markers ${ }^{[7]}$, as it is expressed by 72 $100 \%$ of serous carcinoma and absent of the normal tissue ${ }^{[5,21,22]}$, and as it allows incorporation of conjugated compounds by endocytosis into cancerous cell cytoplasm.

Folate receptor molecular targeting for diagnosis (imaging,...) or therapy (chemotherapy / radiotherapy) is so a topic of research for more than twenty years ${ }^{[23]}$, and it has been observed an excellent tumor specificity allowing performing fluorescence-guided surgery ${ }^{[24]}$, or FR-positive tissue imaging ${ }^{[19]}$.

Thus, folate has been conjugated to a fluorescent dye (fluorescein-isothiocyanate) to enhance fluorescence-guided surgery in women with peritoneal metastasis requiring a complete cytoreductive surgery [24]. Authors showed a perfect correlation between fluorescence and histology to precisely detect peritoneal metastasis, and this is strong evidence to show the accuracy of folate receptor to address molecular compound. Our results are leading to the same conclusions and we have observed a strong correlation between tissue expression of FRa determined by IHC, and tissue accumulation of the PS observed both by porphyrin tissue quantification and direct visualization by confocal microscopy under the form of specific red endocytosis vesicles. This observation is in agreement with numerous authors who have stated that membrane anchored FR $\alpha$ can mediate internalization of receptor-bound folate compounds and folate conjugates into cytoplasm of cells by endocytosis ${ }^{[6,13,21,24]}$.

Molecularly targeted PS are needed to improve therapeutic index of intraperitoneal PDT ${ }^{[12]}$. Indeed, existing PS have been evaluated in intraperitoneal indication and their lack of specificity for tumor tissue was responsible for a poor tolerance of the procedure. The tumorto-normal tissue ratio allows understanding the high grade morbidity observed both in preclinical and clinical studies. 
Protoporphyrin IX which accumulates into tissue after administration of an exogenous precursor (hexaminolevulinate) has been tested in preclinical studies for intraperitoneal application. We have already observed that poor tolerance was imputable to a higher level of PS in other organs of the cavity than in tumor ${ }^{[25]}$.

In human application, only porfimer sodium has been clinically evaluated in phase I and II trials ${ }^{[26-30]}$. Severe complications, as digestive perforation, capillary leaks syndrome ${ }^{[31]}$, prolonged stay in intensive care unit, have been reported without benefit on progression-free survival or on global survival. Those complications are related to a low tumor-to-normal tissue ratio measured from 143 samples of 48 patients at a mean value of $2.1^{\text {[32] }}$

Our results are in favor of an enhancement of this ratio. A mean ratio of 9.6 should permit to illuminate the peritoneal cavity without inducing visceral injuries. This ratio includes results obtained from ovary and this organ would be removed in case of surgery for ovarian cancer, but results regarding colon and small intestine (tumor-to-tissue ratio $=26$ and 48 respectively) indicate that it could be possible to illuminate those organs with appropriate wavelength without risking a digestive perforation.

Tissue quantification has been performed by an expert team regarding tissue porphyrin quantification, and the PS used in this study has been obtained by chemical synthesis so no interference with endogenous porphyrin could have occurred during the quantification.

In conclusion, intraperitoneal PDT could offer the opportunity to decrease peritoneal recurrence rate which is a challenge to raise in order to increase survival of patient. A new specific PS is needed to make feasible a safe human evaluation. We need to assess the efficacy of this specific PS to induce necrosis in photodynamic conditions. Further preclinical studies are conducted by our team to evaluate tolerance and photodynamic efficacy in vivo. Others applications using a folate-targeted PS could be considered for other cancers which overexpress folate receptor alpha. 


\section{CONFLICT OF INTEREST STATEMENT}

The authors declare that there have no conflicts of interest.

\section{ACKNOWLEDGMENT}

This research was supported by SIRIC ONCOLille, Grant INCa-DGOS-Inserm 6041.

The authors thank Sylvie Simonin (Centre Français des Porphyries) for her technical work for tissue porphyrin quantification.

\section{References}

1. Eisenkop SM, Spirtos NM, Lin W-CM. "Optimal" cytoreduction for advanced epithelial ovarian cancer: A commentary. Gynecol Oncol 2006;103(1):329-35.

2. Vergote I, Amant F, Kristensen G, Ehlen T, Reed NS, Casado A. Primary surgery or neoadjuvant chemotherapy followed by interval debulking surgery in advanced ovarian cancer. Eur J Cancer 2011;47, Supplement 3:S88-S92.

3. Al Rawahi T, Lopes AD, Bristow RE, Bryant A, Elattar A, Chattopadhyay S, et al. Surgical cytoreduction for recurrent epithelial ovarian cancer. Cochrane Database Syst Rev 2013;2:CD008765.

4. Elias D, Goéré D, Dumont F, Honoré C, Dartigues P, Stoclin A, et al. Role of hyperthermic intraoperative peritoneal chemotherapy in the management of peritoneal metastases. Eur $\mathrm{J}$ Cancer Oxf Engl 1990 2014;50(2):332-40.

5. Kalli KR, Oberg AL, Keeney GL, Christianson TJH, Low PS, Knutson KL, et al. Folate receptor alpha as a tumor target in epithelial ovarian cancer. Gynecol Oncol 2008;108(3):619-26.

6. Sudimack J, Lee RJ. Targeted drug delivery via the folate receptor. Adv Drug Deliv Rev $2000 ; 41(2): 147-62$.

7. Jayson GC, Kohn EC, Kitchener HC, Ledermann JA. Ovarian cancer. The Lancet 2014;384(9951):1376-88.

8. Gravier J, Schneider R, Frochot C, Bastogne T, Schmitt F, Didelon J, et al. Improvement of meta-tetra (hydroxyphenyl) chlorin-like photosensitizer selectivity with folate-based targeted delivery. Synthesis and in vivo delivery studies. J Med Chem 2008;51(13):3867-77.

9. Schneider R, Schmitt F, Frochot C, Fort Y, Lourette N, Guillemin F, et al. Design, synthesis, and biological evaluation of folic acid targeted tetraphenylporphyrin as novel photosensitizers for selective photodynamic therapy. Bioorg Med Chem 2005;13(8):2799-808.

10. Rose GS, Tocco LM, Granger GA, DiSaia PJ, Hamilton TC, Santin AD, et al. Development and characterization of a clinically useful animal model of epithelial ovarian cancer in the Fischer 344 rat. Am J Obstet Gynecol 1996;175(3 Pt 1):593-9. 
11. Azaïs H, Queniat G, Bonner C, Kerdraon O, Tardivel M, Jetpisbayeva G, et al. Fischer 344 rat: a preclinical model for epithelial ovarian cancer folate-targeted therapy. Int $\mathrm{J}$ Gynecol Cancer 2015; DOI 10.1097/IGC.0000000000000497. In press.

12. Cengel KA, Glatstein E, Hahn SM. Intraperitoneal photodynamic therapy. Cancer Treat Res 2007;134:493-514.

13. Elnakat $\mathrm{H}$, Ratnam $\mathrm{M}$. Distribution, functionality and gene regulation of folate receptor isoforms: implications in targeted therapy. Adv Drug Deliv Rev 2004;56(8):1067-84.

14. Azaïs H, Moussaron A, Khodja Bach S, Bassil A, Betrouni N, Frochot C, et al. FRa: a target for prophylactic photodynamic therapy of ovarian peritoneal metastasis? Bull Cancer (Paris) 2014;101(12):1109-13.

15. Despierre E, Lambrechts S, Leunen K, Berteloot P, Neven P, Amant F, et al. Folate receptor alpha (FRA) expression remains unchanged in epithelial ovarian and endometrial cancer after chemotherapy. Gynecol Oncol 2013;130(1):192-9.

16. Crane LMA, Arts HJG, Oosten M, Low PS, Zee AGJ, Dam GM, et al. The effect of chemotherapy on expression of folate receptor-alpha in ovarian cancer. Cell Oncol 2011;35(1):9-18.

17. Moret F, Scheglmann D, Reddi E. Folate-targeted PEGylated liposomes improve the selectivity of PDT with meta-tetra(hydroxyphenyl)chlorin (m-THPC). Photochem Photobiol Sci $2013 ; 12(5): 823$.

18. Li D, Li P, Lin H, Jiang Z, Guo L, Li B. A novel chlorin-PEG-folate conjugate with higher water solubility, lower cytotoxicity, better tumor targeting and photodynamic activity. J Photochem Photobiol B 2013;127C:28-37.

19. Naumann RW, Coleman RL, Burger RA, Sausville EA, Kutarska E, Ghamande SA, et al. PRECEDENT: A Randomized Phase II Trial Comparing Vintafolide (EC145) and Pegylated Liposomal Doxorubicin (PLD) in Combination Versus PLD Alone in Patients With PlatinumResistant Ovarian Cancer. J Clin Oncol 2013;:JCO.2013.49.7685.

20. Razzak M. Gynaecological cancer: Vintafolide-targeting the folate receptor with a cytotoxic offers hope. Nat Rev Clin Oncol 2013;10(12):668.

21. Parker N, Turk MJ, Westrick E, Lewis JD, Low PS, Leamon CP. Folate receptor expression in carcinomas and normal tissues determined by a quantitative radioligand binding assay. Anal Biochem 2005;338(2):284-93.

22. O'Shannessy DJ, Somers EB, Smale R, Fu Y-S. Expression of folate receptor-a (FRA) in gynecologic malignancies and its relationship to the tumor type. Int $J$ Gynecol Pathol Off $J$ Int Soc Gynecol Pathol 2013;32(3):258-68.

23. Leamon CP, Low PS. Delivery of macromolecules into living cells: a method that exploits folate receptor endocytosis. Proc Natl Acad Sci 1991;88(13):5572-6.

24. Van Dam GM, Themelis G, Crane LMA, Harlaar NJ, Pleijhuis RG, Kelder W, et al. Intraoperative tumor-specific fluorescence imaging in ovarian cancer by folate receptor- $\alpha$ targeting: first inhuman results. Nat Med 2011;17(10):1315-9.

25. Guyon L, Farine M-O, Lesage JC, Gevaert A-M, Simonin S, Schmitt C, et al. Photodynamic therapy of ovarian cancer peritoneal metastasis with hexaminolevulinate: a toxicity study. Photodiagnosis Photodyn Ther 2014;

26. Delaney TF, Sindelar WF, Tochner Z, Smith PD, Friauf WS, Thomas G, et al. Phase I study of debulking surgery and photodynamic therapy for disseminated intraperitoneal tumors. Int $\mathrm{J}$ Radiat Oncol 1993;25(3):445-57. 
27. Sindelar WF, Sullivan FJ, Abraham E, DeLaney TF, Smith PD, Friauf GF, et al. Intraperitoneal photodynamic therapy shows efficacy in phase I trial. In: Proc Am Soc Clin Oncol. 1995. page 447.

28. Sindelar WF, DeLaney TF, Tochner Z, et al. Technique of photodynamic therapy for disseminated intraperitoneal malignant neoplasms: Phase i study. Arch Surg 1991;126(3):31824.

29. Hahn SM, Fraker DL, Mick R, Metz J, Busch TM, Smith D, et al. A Phase II Trial of Intraperitoneal Photodynamic Therapy for Patients with Peritoneal Carcinomatosis and Sarcomatosis. Clin Cancer Res 2006;12(8):2517-25.

30. Hendren SK, Hahn SM, Spitz FR, Bauer TW, Rubin SC, Zhu T, et al. Phase II trial of debulking surgery and photodynamic therapy for disseminated intraperitoneal tumors. Ann Surg Oncol 2001;8(1):65-71.

31. Canter RJ, Mick R, Kesmodel SB, Raz DJ, Spitz FR, Metz JM, et al. Intraperitoneal photodynamic therapy causes a capillary-leak syndrome. Ann Surg Oncol 2003;10(5):514-24.

32. Hahn SM, Putt ME, Metz J, Shin DB, Rickter E, Menon C, et al. Photofrin uptake in the tumor and normal tissues of patients receiving intraperitoneal photodynamic therapy. Clin Cancer Res Off J Am Assoc Cancer Res 2006;12(18):5464-70.

\section{LEGENDS}

\section{Figure 1}

a) 5-(4-carboxyphenyl)-10,15,20-triphenylporphyrin (Porph)

b) N-\{2-[2-(2-aminoethoxy)ethoxy]ethyl\}folic acid\}-4-carboxyphenylporphyrin (Porph-s-FA)

\section{Figure 2}

Tissue expression of FRa by each studied organ, and observation of a specific signal in confocal microscopy indicating the presence of Porph-s-FA which accumulates in red vesicles of endocytosis in tissue that expressed FRa (DAPI : Cell nuclei).

\section{Figure 3}

A : Subcutaneous tumor at the injection site of NuTu-19 cells. Muscular tissue infiltration by tumor (H\&E. 20x) B : Diaphragmatic peritoneal metastasis with a central necrosis zone (H\&E. 20x.) D : Tumoral tissu. Weak FRa staining. 20x. F : Tumoral tissue. Strong FRa staining (arrows). 20x. C (10x) and E (40x) : Confocal microscopy. Heterogenous intracellular signal corresponding to tissular Porphs-FA incorporation. 


\section{Figure 4}

Tissue concentration of photosensitizer (nmol / g prot), 4 hours after its intraperitoneal administration.

\section{Figure 5}

Tissue concentration of photosensitizer ( $\mathrm{nmol} / \mathrm{g}$ prot), 4 hours after its intraperitoneal administration.

Details. (Group 1 : Control / Group 2 : Porph / Group 3 : Porph-s-FA)

\section{Table 1}

Tissue concentration of photosensitizer (nmol/g prot.) Mean +/- SD

\section{Table 2}

Tissue concentration of photosensitizer ( $\mathrm{nmol} / \mathrm{g}$ prot.). Details.

Table 1 : Tissue concentration of photosensitizer (nmol / g prot.) Mean +/- SD

\begin{tabular}{cccc}
\hline & Group 1 & Group 2 & Group 3 \\
\hline Peritoneum & $0.37+/-0.20$ & $4.17+/-6.51$ & $2.82+/-1.91$ \\
Kidney & $0.80+/-0.00$ & $0.70+/-0.27$ & $1.03+/-0.72$ \\
Small Bowel & $0.53+/-0.08$ & $2.15+/-2.37$ & $1.82+/-1.00$ \\
Colon & $0.48+/-0.17$ & $3.57+/-5.15$ & $3.27+/-2.97$ \\
Liver & $0.40+/-0.00$ & $1.77+/-1.48$ & $10.25+/-5.69$ \\
Ovary & $0.17+/-0.06$ & $10.90+/-13.87$ & $35.30+/-31.52$ \\
\hline
\end{tabular}


Table 2 : Tissue concentration of photosensitizer ( $\mathrm{nmol} / \mathrm{g}$ prot.). Details.

\begin{tabular}{|c|c|c|c|c|c|c|c|}
\hline & Rat id. & Kidney & Liver & $\begin{array}{c}\text { Small } \\
\text { Intestine }\end{array}$ & Colon & Peritoneum & Ovary \\
\hline \multirow{6}{*}{$\begin{array}{c}\text { Group } \\
1\end{array}$} & 1 & 0.8 & 0.4 & 0.4 & 0.3 & 0.3 & - \\
\hline & 2 & 0.8 & 0.4 & 0.6 & 0.6 & 0.5 & 0.2 \\
\hline & 3 & 0.8 & 0.4 & 0.5 & 0.7 & 0.2 & - \\
\hline & 4 & 0.8 & 0.4 & 0.5 & 0.3 & 0.7 & 0.2 \\
\hline & 5 & 0.8 & 0.4 & 0.6 & 0.4 & 0.3 & 0.1 \\
\hline & 6 & 0.8 & 0.4 & 0.6 & 0.6 & 0.2 & - \\
\hline \multirow{6}{*}{$\begin{array}{c}\text { Group } \\
2\end{array}$} & 1 & 0.4 & 0.3 & 0.2 & 0.1 & 0.1 & 0.1 \\
\hline & 2 & 0.5 & 0.5 & 0.1 & 0.1 & 0.1 & 0.2 \\
\hline & 3 & 1 & 3.1 & 2.6 & 1.6 & 16.9 & 12.4 \\
\hline & 4 & 1 & 2.7 & 3.9 & 3.8 & 4.2 & 34.7 \\
\hline & 5 & 0.5 & 0.5 & 0.3 & 2.1 & 0.1 & 0.2 \\
\hline & 6 & 0.8 & 3.5 & 5.8 & 13.7 & 3.6 & 17.8 \\
\hline \multirow{6}{*}{$\begin{array}{c}\text { Group } \\
\mathbf{3}\end{array}$} & 1 & 0.6 & 13.6 & 1.3 & 2.3 & 2.3 & 3.2 \\
\hline & 2 & 2.5 & 9 & 3.6 & 7.7 & 1.9 & 22 \\
\hline & 3 & 0.7 & 1.1 & 0.6 & 1.1 & 2.1 & 19.4 \\
\hline & 4 & 0.8 & 7.1 & 2 & 0.7 & 0.5 & 19.6 \\
\hline & 5 & 0.8 & 16.7 & 1.6 & 1.5 & 5.1 & 86 \\
\hline & 6 & 0.8 & 14 & 1.8 & 6.3 & 5 & 61.6 \\
\hline
\end{tabular}



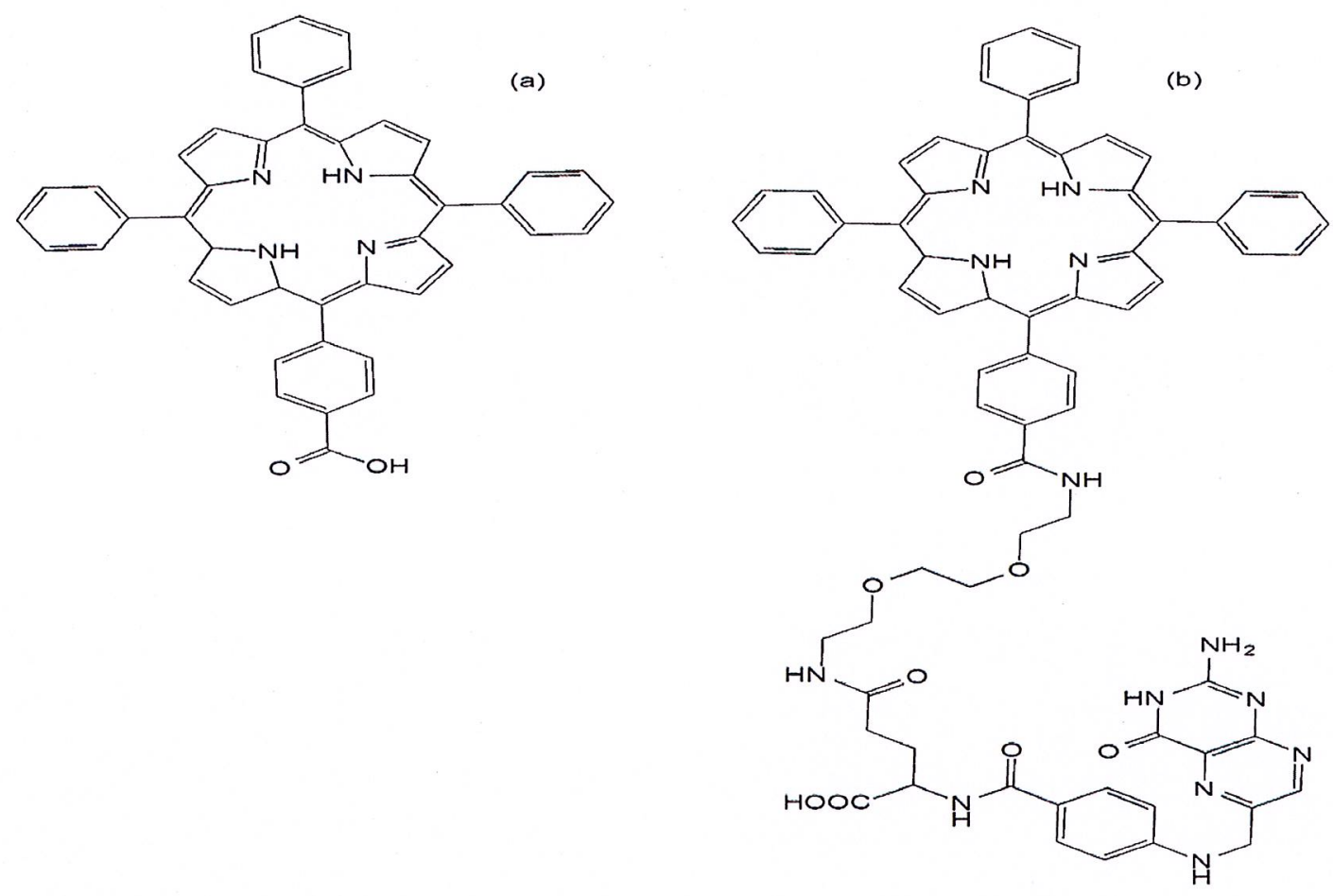

Figure 1 - $300 \mathrm{dpi}$. 


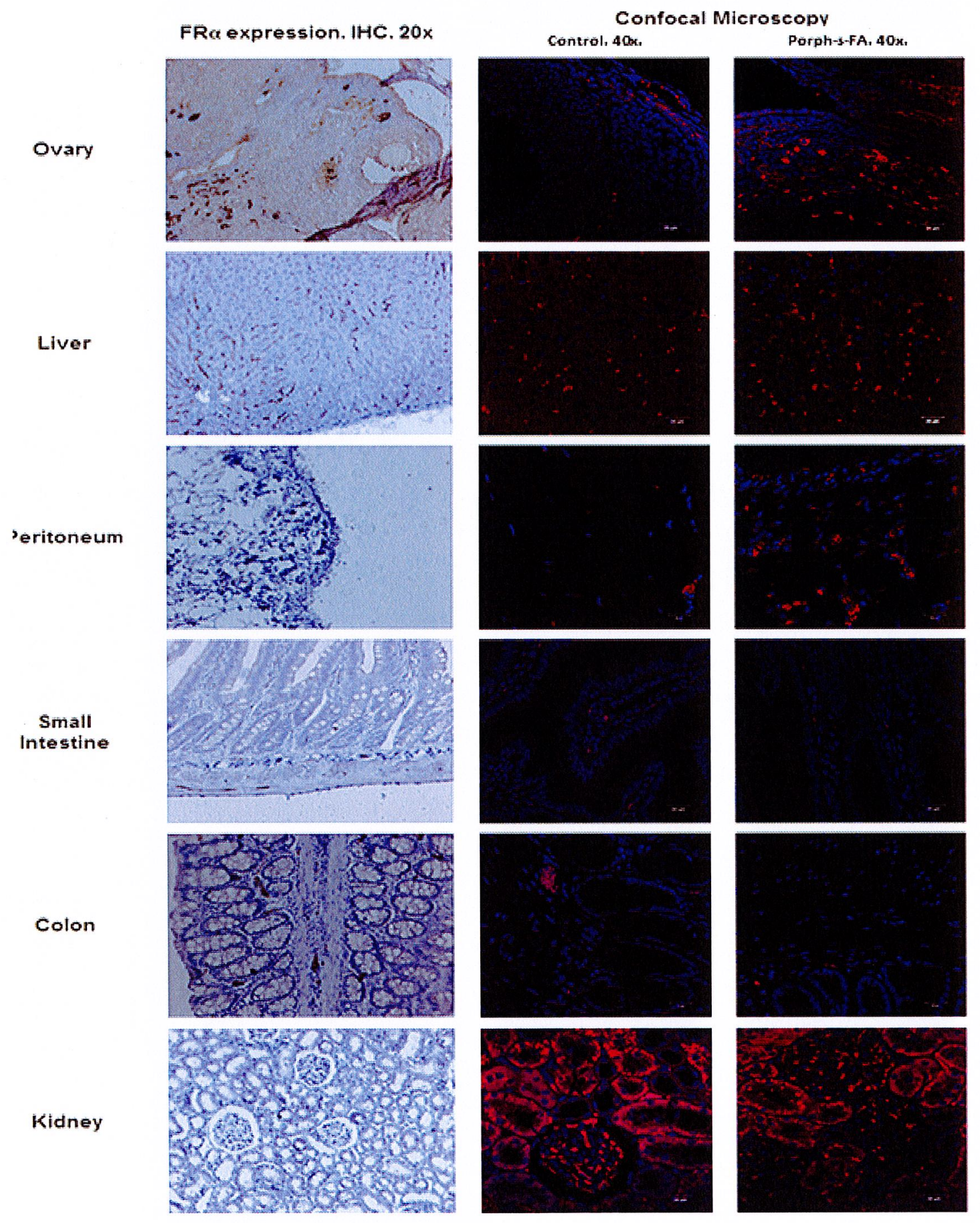

Figure 2 - $300 \mathrm{dpi}$. 


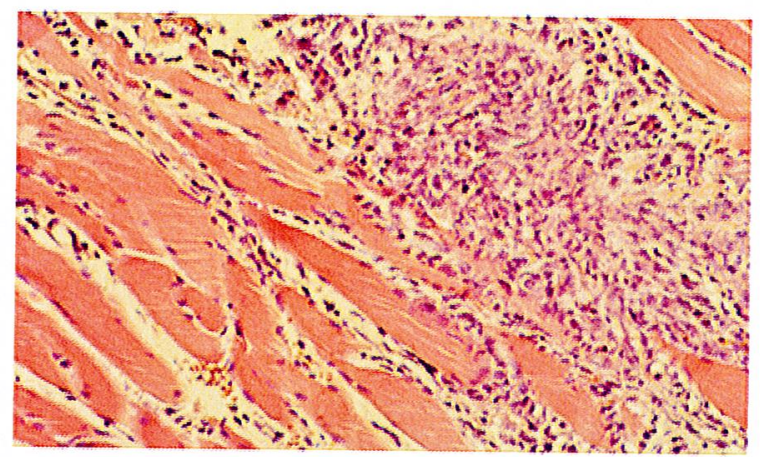

A

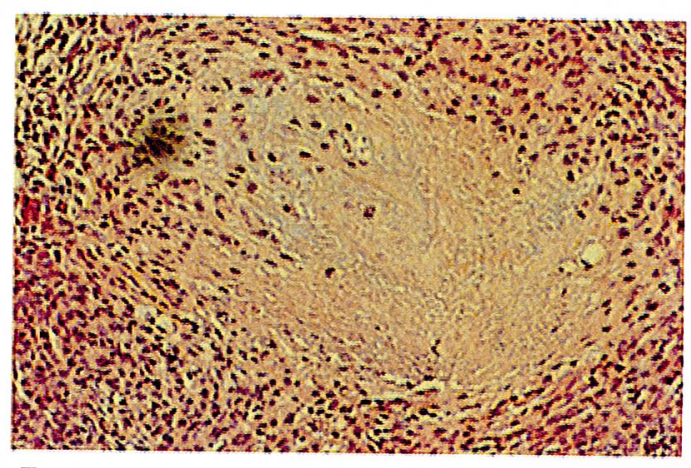

B
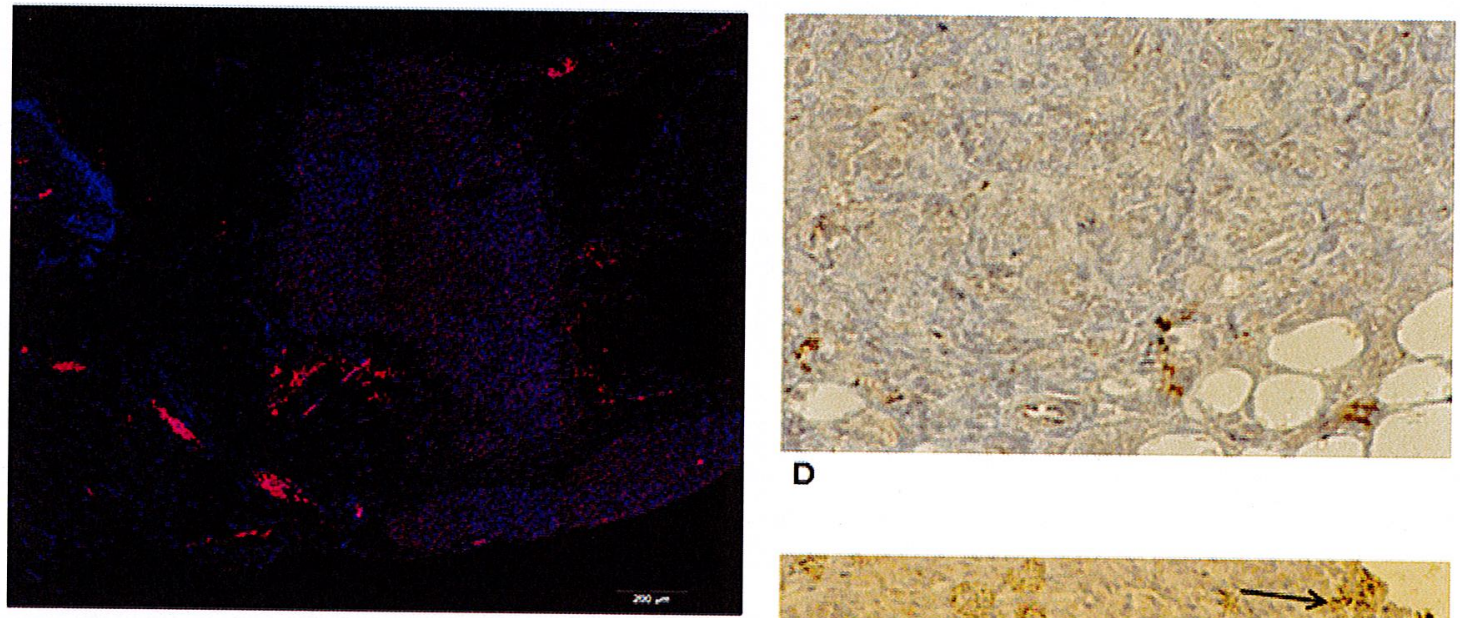

C

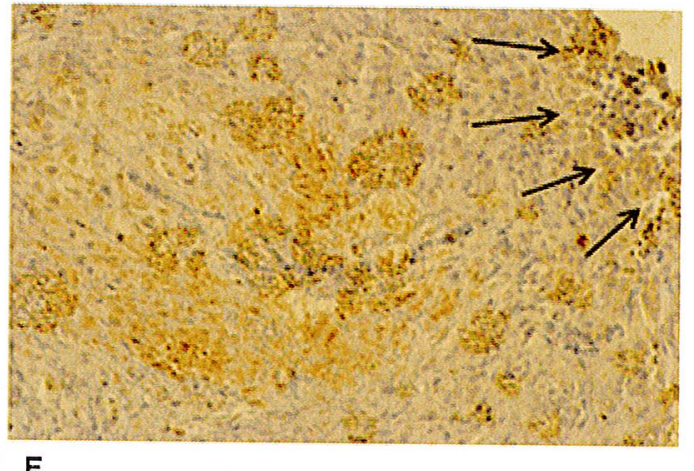

E

F

Figure $3-300 \mathrm{dpi}$. 


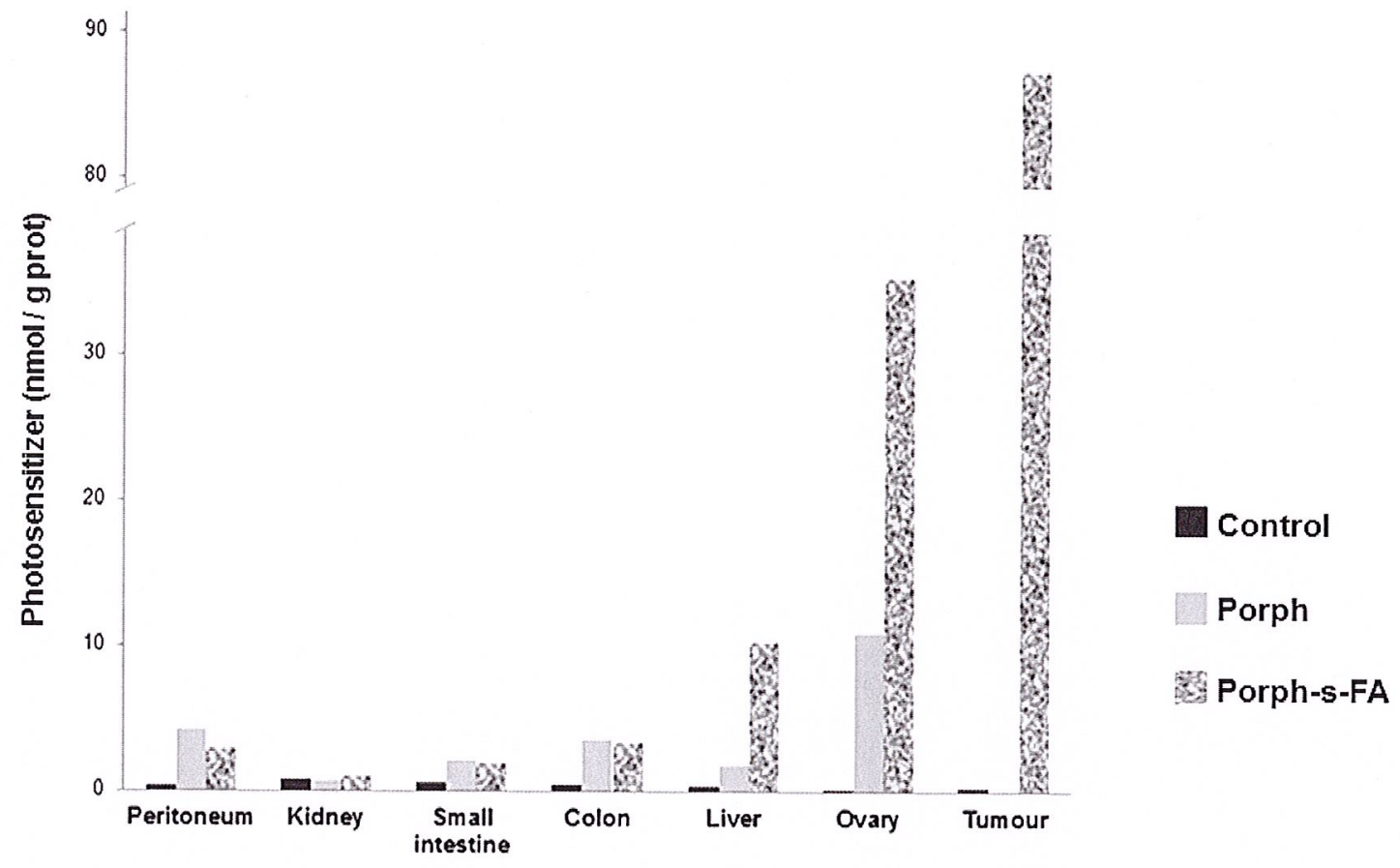

Figure 4 - 300 dpi 

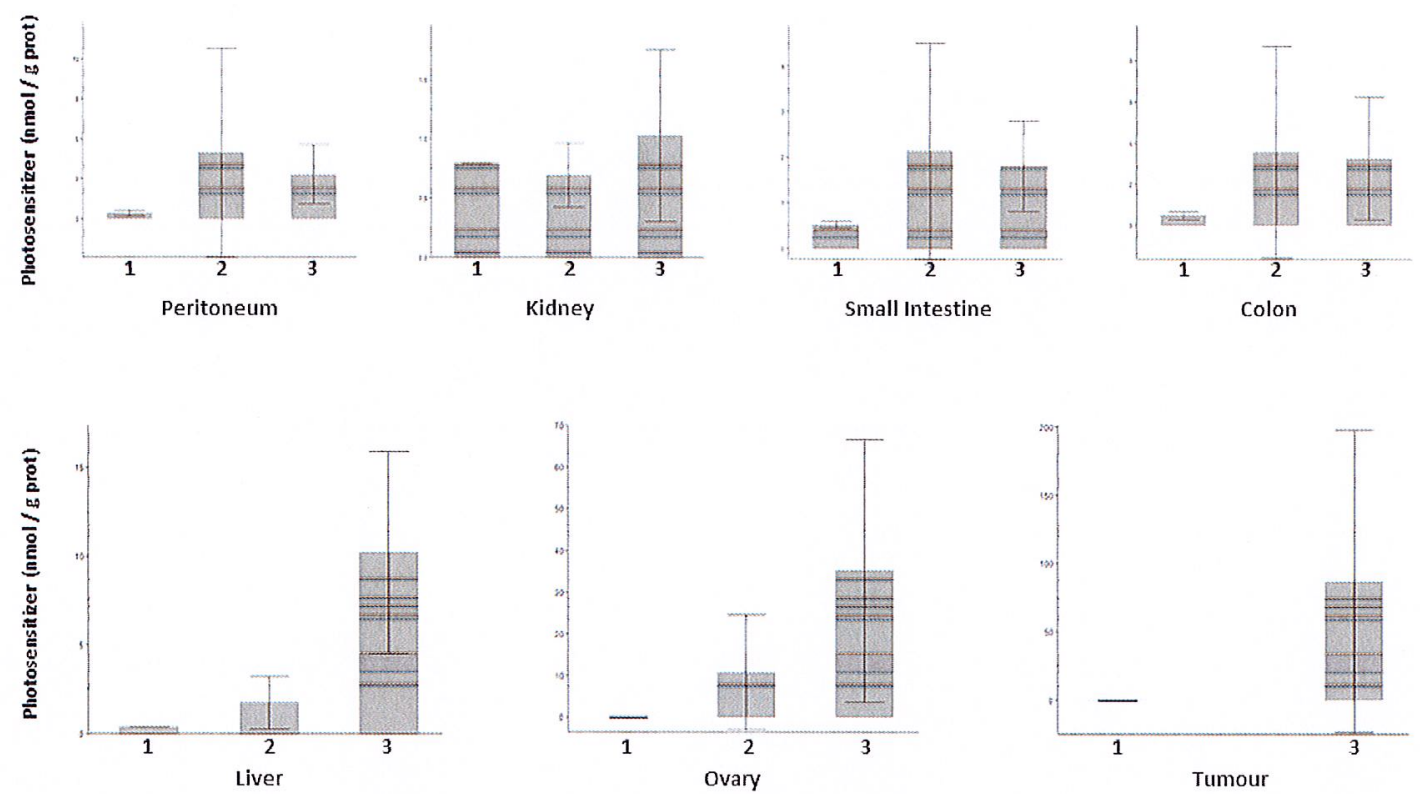

Figure 5 - $300 \mathrm{dpi}$. 